\title{
Defragmentasi Struktur Berpikir Siswa Impulsif dalam Memecahkan Masalah Geometri
}

\author{
Puspita Ayu Damayanti ${ }^{1}$, Subanji ${ }^{1}$, Sukoriyanto ${ }^{1}$ \\ ${ }^{1}$ Pendidikan Matematika-Universitas Negeri Malang
}

\section{INFO ARTIKEL}

\section{Riwayat Artikel:}

Diterima: 30-08-2019

Disetujui: 10-03-2020

\section{Kata kunci:}

defragmentation of thinking structures,

impulsive;

geometry;

defragmentasi struktur berpikir;

impulsif;

geometri;

\author{
Alamat Korespondensi: \\ Puspita Ayu Damayanti \\ Pendidikan Matematika \\ Universitas Negeri Malang \\ Jalan Semarang 5 Malang \\ E-mail: pitapus317@gmail.com
}

\begin{abstract}
ABSTRAK
Abstract: This study aims to describe the defragmentation process of impulsive student's thinking structures in solving geometry problems. This research was conducted on two students of $9^{\text {th }}$ grade of SMPN 1 Puncu. The research data were obtained throught the providing of MFFT and problem solving tests. The result of this research showed that the defragmentation of students mistakes in providing initial ideas for problem solving was done throught cognitive conflict, scaffolding, and disequilibration. Defragmentation to form knowledge schemes and bring up schemes that already owned to solve the problems were done throught disequilibration and level 2 of scaffolding (explaining, reviewing, restructuring). Defragmentation to practice students to do reflection was done throught level 1 of scaffolding (environmental provisions).
\end{abstract}

\begin{abstract}
Abstrak: Penelitian ini bertujuan untuk mendeskripsikan proses defragmentasi struktur berpikir siswa impulsif dalam memecahkan masalah geometri. Penelitian ini dilakukan pada dua siswa kelas IX SMPN 1 Puncu. Data penelitian diperoleh melalui pemberian MFFT dan tes pemecahan masalah. Hasil penelitian ini menunjukkan bahwa defragmentasi kesalahan siswa dalam memberikan gagasan awal untuk pemecahan masalah dilakukan melalui konflik kognitif, scaffolding, dan disekuilibrasi. Defragmentasi untuk membentuk skema pengetahuan dan memunculkan skema yang sudah dimiliki untuk memecahkan masalah dilakukan melalui disekuilibrasi dan scaffolding level 2 (explaining, reviewing, restructuring). Defragmentasi untuk melatih siswa melakukan refleksi dilakukan melalui scaffolding level 1 (environmental provisions).
\end{abstract}

Kemampuan pemecahan masalah penting untuk dimiliki siswa. NCTM (2000) telah merumuskan lima standar proses pembelajaran salah satunya adalah kemampuan pemecahan masalah. Pembelajaran harus dirancang sedemikian hingga mampu memberikan pengalaman kepada siswa dalam memecahkan masalah. Pembelajaran yang demikian dapat lebih efektif. Hal ini diungkap oleh Hassanabad, Shahvarani, \& Behzadi (2012) bahwa pembelajaran matematika lebih efektif ketika melibatkan pemecahan masalah. Novotná (2014) menegaskan bahwa kesuksesan pembelajaran matematika didasari oleh pemecahan masalah. Ketika siswa memecahkan masalah, kemampuan berpikirnya dapat berkembang (Pimta, Tayruakham, \& Nuangchale, 2009). Kemampuan pemecahan masalah juga sangat diperlukan dalam kehidupan yang semakin kompleks (Kaur \& Toh, 2016).

Salah satu masalah dalam matematika melibatkan materi geometri. Geometri merupakan materi penting dalam matematika (Kultuca, 2013; Aydogdu \& Kesan, 2014). Menurut Y1lmaz \& Koparan (2015) pembelajaran geometri dapat memfasilitasi siswa dalam pemecahan masalah. Masalah yang berkaitan dengan geometri sangat sering dijumpai di kehidupan salah satunya di bidang arsitektur (Madden, 2017). Dalam sistem pendidikan di Indonesia, kompetensi siswa dalam bidang geometri juga telah dirumuskan dalam Permendikbud Nomor 24 Tahun 2016 . Oleh karena itu, geometri perlu dikuasai siswa. Kondisi di sekolah menunjukkan bahwa masih ada siswa yang mengalami kesalahan dalam memecahkan masalah geometri. Beberapa hasil penelitian juga menunjukkan hal yang sama. Masalah geometri yang disajikan dalam bentuk cerita dapat mengakibatkan siswa mengalami kesalahan dalam memecahkannya (Seifi, Haghverdi, \& Azizmohamadi, 2012). Kesalahan siswa dalam memecahkan masalah geometri dapat terjadi karena siswa tidak menganalisa masalah dengan baik (Gal \& Linchevcki, 2010). Selain itu, kesalahan muncul karena siswa tidak mengaitkan masalah dengan pengetahuan lain (Biber, Tuna, \& Korkmaz, 2013). Hal ini mengindikasikan bahwa terjadi kesalahan dalam strukur berpikir siswa. 
Struktur berpikir merupakan struktur kognitif yang terbentuk ketika siswa memecahkan masalah (Barnard \& Tall, 1997). Kesalahan struktur berpikir dapat diperbaiki sehingga akan sesuai dengan struktur masalahnya. Salah satu cara untuk memperbaiki struktur berpikir adalah melalui defragmentasi (Selvera, 2013). Defragmentasi dapat diartikan sebagai suatu proses menata kembali struktur berpikir siswa dalam memecahkan masalah (Subanji, 2016). Proses menata kembali struktur berpikir dapat dilakukan melalui identifikasi kesalahan berpikir dan menata ulang pikiran yang salah menjadi benar (McKay \& Fanning, 2000). Identifikasi kesalahan dapat diketahui pada tulisan siswa dalam pemecahan masalah maupun wawancara mendalam.

Struktur berpikir dapat ditata kembali melalui berbagai cara, seperti konflik kognitif, disekuilibrasi, dan scaffolding (Subanji, 2016). Konflik kognitif dilakukan melalui pemberian pertanyaan-pertanyaan yang bertentangan dengan proses yang dilakukan siswa (Subanji, 2016). Disekuilibrasi dilakukan melalui pemberian pertanyaan yang menimbulkan kesenjangan berpikir siswa yang dapat membuat siswa merefleksi jawabannya (Subanji, 2016). Scaffoling merupakan pemberian bantuan kepada siswa dalam proses pembelajaran kemudian menghilangkannya ketika siswa mulai sanggup (Slavin, 2008). Scaffolding yang dapat diberikan kepada siswa terdiri dari tiga level (Anghileri, 2006). Level 1 (environmental provisions) berupa bantuan bukan pada konten matematika secara langsung namun pada lingkungan belajar. Level 2 (explaining, reviewing, and restructuring) bantuan yang diberikan fokus pada konten matematika. Bantuan yang diberikan dapat berupa pertanyaan untuk mengarahkan siswa mengidentifikasi semua aspek yang terkait masalah, mendorong siswa menyampaikan gagasan serta justifikasinya, maupun untuk membuat penekanan pada diskusi yang dilakukan. Level ketiga (making connections and generating conceptual discourse) merupakan perluasan dari justifikasi pada level 2 yang mengakibatkan munculnya banyak konsep.

Defragmentasi struktur berpikir dilakukan pada siswa yang mengalami kesalahan struktur berpikir ditinjau dari gaya kognitif. Gaya kognitif merupakan kecenderungan seseorang dalam mengingat, mengatur, memproses informasi dan menyelesaikan masalah (Liu \& Ginther, 1999). Ditinjau dari konseptual tempo, gaya kognitif dapat dibedakan menjadi gaya kognitif reflektif dan impulsif (Santrock, 2011). Gaya kognitif reflektif merupakan kecenderungan siswa memecahkan masalah dengan waktu yang relatif lama namun cermat, sedangkan gaya kognitif impulsif merupakan kecenderungan siswa memecahkan masalah dengan waktu yang relatif singkat, tetapi tidak cermat sehingga jawaban yang dihasilkan cenderung salah (Shaban, Ramazani, \& Alipoor, 2017). Pada penelitian ini, siswa dengan gaya kognitif impulsif dipilih karena karakteristiknya yang tidak cermat sehingga lebih banyak kesalahan yang dilakukannya. Dengan demikian, artikel ini mendeskripsikan defragmentasi struktur berpikir siswa impulsif dalam memecahkan masalah matematika.

\section{METODE}

Penelitian ini menggunakan pendekatan kualitatif naratif. Penelitian ini dilakukan di SMPN 1 Puncu. Siswa diberikan instrumen berupa lembar MFFT untuk diketahui gaya kognitifnya. Selanjutnya, siswa diberikan tes pemecahan masalah untuk menentukan kesalahan siswa dalam memecahkan masalah geometri yang selanjutnya dilakukan wawancara mendalam sebagai proses defragmentasi. Masalah geometri yang digunakan dalam penelitian ini adalah sebagai berikut.

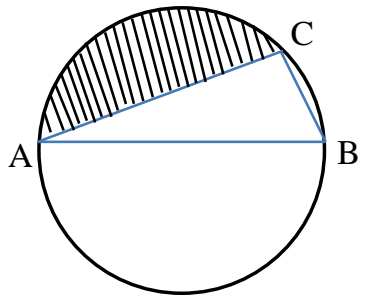

Diberikan lingkaran seperti pada gambar di samping. $\overline{A B}$ adalah tali busur terpanjang pada lingkaran tersebut. Panjang busur $A C$ minor $\frac{53 \pi}{9} \mathrm{~cm}$. Jika $A C=16 \mathrm{~cm}$ dan ukuran $\angle C B A$ adalah $53^{\circ}$, maka berapakah luas daerah yang diarsir?

Prosedur analisis pada penelitian ini dilakukan melalui tiga tahap, yaitu mereduksi data, menyajikan data, dan menarik simpulan. Pada tahap mereduksi data dilakukan pemilahan siswa dengan gaya kognitif impulsif yang melakukan kesalahan dalam memecahkan masalah geometri. Siswa impulsif yang melakukan kesalahan kembali direduksi disesuaikan dengan kemampuan komunikasi siswa. Selanjutnya, pada tahap menyajikan data disajikan siswa sebagai subjek setelah proses reduksi data. Disajikan pula struktur berpikir subjek sebelum dan sesudah proses defragmentasi. Kesimpulan yang diperoleh pada tahap menarik simpulan adalah deskripsi defragmentasi struktur berpikir yang dilakukan kepada siswa impulsif.

\section{HASIL}

Berdasarkan hasil pengerjaan MFFT diperoleh bahwa dari 21 siswa terdapat delapan siswa dengan gaya kognitif impulsif. Setelah diberikan instrumen pelacak dan tes pemecahan masalah diperoleh dua siswa yang memiliki banyak skema terkait lingkaran untuk pemecahan masalah dengan kemampuan komunikasi yang baik. Dua siswa tersebut adalah NY dan NS yang selanjutnya sebagai subjek. Berikut ini didekripsikan struktur berpikir siswa dalam memecahkan masalah geometri sebelum dan saat proses defragmentasi. 


\section{Deskripsi Struktur Berpikir NY dalam Memecahkan Masalah Geometri Sebelum Defragmentasi}

Masalah geometri yang diberikan tidak dapat diselesaikan NY dengan baik. Struktur berpikir NY dalam memecahkan masalah geometri belum sesuai dengan struktur masalahnya. Pada lembar jawaban, NY menuliskan bahwa daerah yang diarsir dapat dianggap sebagai lingkaran baru dengan diameter $A C$ yang panjangnya $16 \mathrm{~cm}$. Jawaban NY disajikan pada gambar 1 .

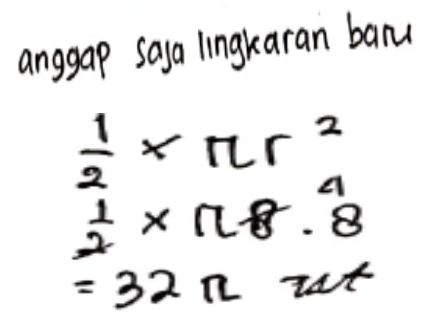

Gambar 1. Jawaban NY terhadap Masalah Geometri

Dalam penjelasannya, NY menyebutkan bahwa daerah yang diarsir dapat dianggap sebagai daerah setengah lingkaran dengan diameter $A C$. Dalam memahami masalah yang diberikan NY tidak memahami makna kalimat "tali busur terpanjang". Namun terlihat bahwa NY sudah memiliki skema terkait tali busur lingkaran merupakan diameter. NY tidak setuju dengan pernyataan bahwa tali busur suatu lingkaran merupakan diameter karena tali busur tidak selalu tepat melewati titik pusat lingkaran dan tidak selalu membagi lingkaran menjadi dua sama besar. Hal ini menunjukkan bahwa tidak semua tali busur dapat menjadi diameter.

Selain skema terkait diameter, terdapat skema-skema terkait lingkaran yang sudah dimiliki NY. Diketahui bahwa NY sudah memiliki skema terkait menentukan luas juring. NY dapat menentukan luas juring yang merupakan seperempat luas lingkaran menggunakan aturan luas juring dengan tepat. Selain itu, diketahui bahwa NY telah memiliki skema terkait menentukan luas segitiga sama kaki. NY mampu menentukan luas segitiga sama kaki yang diketahui panjang ketiga sisinya. NY menentukan tinggi segitiga dengan tepat kemudian menentukan luas segitiga menggunakan aturan luas segitiga dengan tepat pula.

Skema-skema yang sudah dimiliki di atas ternyata tidak mampu dimunculkan oleh NY dalam pemecahan masalah. Hal ini dikarenakan skema terkait tembereng sebagai gagasan awal dalam pemecahan masalah belum dimiliki oleh NY. Soal pelacak terkait tembereng dan luasnya tidak mampu dijawab dengan tepat oleh NY. Selain skema terkait tembereng, NY ternyata juga belum memiliki skema terkait hubungan ukuran sudut pusat dan sudut keliling serta skema terkait menentukan panjang busur lingkaran. Oleh karena itu, diperlukan intervensi untuk pembentukan skema terlebih dahulu sebelum digunakan dalam pemecahan masalah. Deskripsi struktur berpikir NY sebelum defragmentasi disajikan pada Diagram 1 dengan keterangan diagram disajikan pada tabel 1 . Pada diagram tersebut dapat dilihat bahwa hanya skema terkait luas lingkaran yang muncul meskipun menggunakan diameter yang salah.



Gambar 1. Diagram Struktur Berpikir NY Memecahkan Masalah Geometri Sebelum Defragmentasi

\section{Keterangan:}

Langkah Pemecahan masalah tepat

$\longrightarrow$ Alur Pemecahan Masalah

Langkah Pemecahan masalah tidak tepat

$--\rightarrow$ Menunjuk Keterangan 
Tabel 1. Keterangan Gambar Struktur Berpikir NY Memecahkan Masalah Geometri Sebelum Defragmentasi

\begin{tabular}{ll}
\hline Kode & \multicolumn{1}{c}{ Keterangan } \\
\hline $\mathrm{M}$ & Diberikan masalah 1 Tugas 2 \\
$\mathrm{~TB}$ & Menyebutkan $\overline{A B}$ tali busur terpanjang \\
$\mathrm{S}$ & Menyebutkan ukuran $\angle C B A 53^{\circ}$ \\
$\mathrm{PT}$ & Menyebutkan panjang tali busur $A C 16 \mathrm{~cm}$ \\
$\mathrm{~T}$ & Menyebutkan hal yang ditanyakan yaitu daerah yang diarsir (tidak ada penjelasan bahwa daerah yang diarsir adalah luas tembereng) \\
$\mathrm{LT}$ & Menentukan luas daerah yang diarsir yaitu luas setengah lingkaran dengan diameter $A B$ (dianggap lingkaran) \\
\hline
\end{tabular}

\section{Deskripsi Struktur Berpikir NY dalam Memecahkan Masalah Geometri Saat Defragmentasi}

Defragmentasi pertama yang dilakukan bertujuan untuk memperbaiki gagasan awal NY yang menyatakan bahwa pada masalah yang diberikan tembereng dianggap sebagai setengah lingkaran. Defragmentasi dilakukan melalui konflik kognitif seperti dialog berikut.

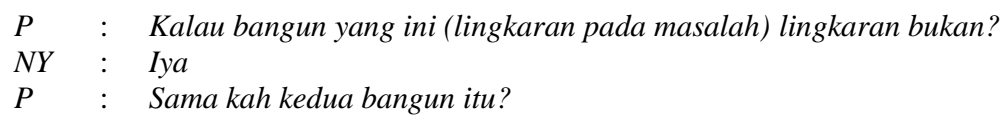

Pada mulanya NY yakin bahwa daerah yang dibuat adalah daerah setengah lingkaran. Namun, setelah diberikan konflik kognitif berupa perintah untuk membandingkan beberapa bangun lingkaran yang tepat dengan lingkaran yang dibuatnya, NY menyadari kesalahannya. Menurut NY daerah yang diarsir pada masalah bukan daerah setengah lingkaran karena lebih lonjong. Dengan ragu, NY memberikan alasan bahwa aturan yang digunakan untuk menentukan luasnya mungkin sama. Dengan demikian, kesalahan gagasan awal terkait konsep lingkaran telah berhasil diperbaiki. Langkah berikutnya adalah defragmentasi yang bertujuan untuk membentuk skema terkait konsep tembereng. Ketika ditanya pengertian tembereng, NY hanya diam. Oleh karena itu, peneliti memberikan scaffolding sebagai berikut.

$$
\begin{aligned}
& P \quad: \quad \text { Coba gambar tembereng } \\
& \text { NY : Ya kayak ini kak } \\
& P \quad: \quad \text { Daerah itu dibatasi sama apa? }
\end{aligned}
$$

Melalui perintah untuk menggambar tembereng diketahui bahwa NY mampu menggambarnya dengan tepat. NY kemudian menjelaskan bahwa tembereng merupakan daerah yang dibatasi oleh tali busur dan busur. Setelah pembentukan skema terkait konsep tembereng, dilakukan pembentukan skema terkait menentukan luas tembereng. Melalui scaffolding dapat diketahui bahwa NY mengetahui juring dapat dibuat melalui titik pusat dan jari-jari serta busur. Melalui pertanyaan "jadi, apa syaratnya juring?" NY memperjelas bahwa syarat juring adalah melalui titik pusat sedangkan gambar pada soal pelacak bukanlah juring karena tidak melalui titik pusat. Melalui intervensi tersebut NY juga mengetahui bahwa luas tembereng adalah selisih dari luas juring dengan luas segitiga pembentuk tembereng.

Skema terkait tembereng dan luasnya yang sudah terbentuk belum dapat dimunculkan oleh NY pada pemecahan masalah. NY hanya diam ketika diminta untuk mulai mengerjakan masalah geometri. Oleh karena itu, peneliti memberikan scaffolding berupa pertanyaan arahan seperti “daerah yang diarsir ini tadi apa?". Pertanyaan yang diberikan menyadarkan NY bahwa daerah yang diarsir adalah tembereng. Kemudian skema terkait menentukan luas tembereng mampu dimunculkan oleh NY.

Setelah NY memunculkan skema terkait tembereng dan luasnya, NY menentukan juring pembentuk tembereng namun mengalami kesalahan. NY menyebutkan juring yang dimaksud adalah sudut $A B C$. Sehingga perlu diberikan intervensi melalui scaffolding. Peneliti memberikan pertanyaan "juring tadi apa?" dan NY langsung menyadari bahwa juring harus melewati titik pusat sehingga NY harus menentukan titik pusat terlebih dahulu. Namun, titik pusat yang dibuat oleh NY tidak tepat. NY menentukan titik pusat berada tepat dibawah titik tengah ruas garis $A B$. Artinya, skema terkait diameter adalah tali busur terpanjang belum muncul. Oleh karena itu, diberikan intervensi berupa scaffolding sebagai berikut.

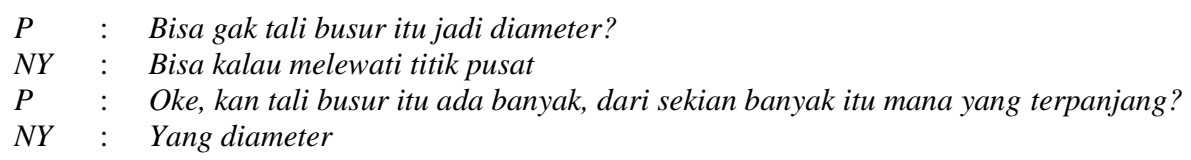

NY menjelaskan bahwa tidak semua tali busur merupakan diameter, tetapi diameter selalu merupakan tali busur. NY juga menjelaskan bahwa diameter adalah tali busur terpanjang. Melalui wawancara yang dilakukan, NY memahami bahwa ruas garis $A B$ yang merupakan tali busur terpanjang adalah diameter. Sehingga NY menentukan titik pusat lingkaran (titik $O$ ) adalah titik tengah ruas garis $A B$. Dengan demikian, NY berhasil menentukan juring pembentuk tembereng dengan tepat yaitu juring $A O C$. 
Setelah berhasil menentukan juring yang dimaksud selanjutnya NY mencoba menentukan luas juring namun bingung karena ukuran sudut pusat belum diketahui. Oleh karena itu, peneliti memberikan intervensi untuk membentuk skema terkait hubugan ukuran sudut pusat dan sudut keliling untuk dimunculkan pada pemecahan masalah. Intervensi diberikan melalui scaffolding. Peneliti memberikan pertanyaan "di soal ini juga ada sudut pusat dan sudut keliling, masih ingat gak hubungannya apa?". Melalui pertanyaan tersebut NY mengingat bahwa ukuran sudut pusat dua kali ukuran sudut keliling. Namun, NY tidak menjelaskan syarat berlakunya aturan tersebut. Setelah diminta untuk mencermati kembali masalah NY menyadari bahwa syarat aturan tersebut adalah kedua sudut harus menghadap busur yang sama. Dengan demikian, NY berhasil menentukan ukuran sudut pusat dengan tepat yaitu $106^{\circ}$ melalui ukuran sudut keliling yang diketahui.

Langkah selanjutnya adalah menentukan panjang jari-jari lingkaran untuk dapat menentukan luas juring. Namun NY tidak dapat menetukannya karena belum memiliki skema terkait menentukan aturan panjang busur. Berikut diberikan intervensi berupa scaffolding.

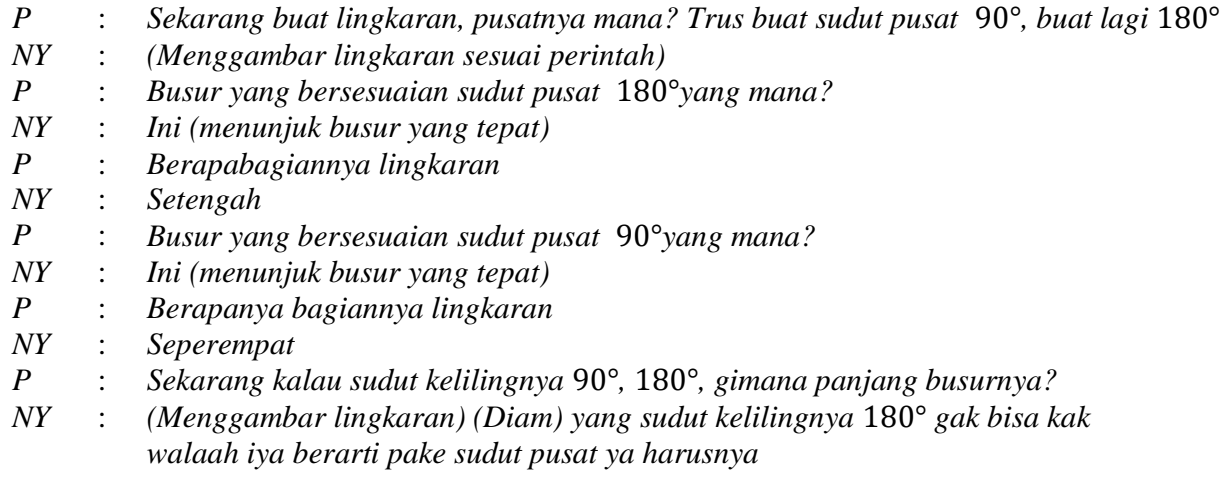

Melalui wawancara yang diberikan dimana NY diminta untuk membuat kesimpulan dari pernyataan untuk dibandingkan NY mampu menentukan bahwa dalam menentukan panjang busur menggunakan ukuran sudut pusat bukan sudut keliling. NY juga mampu menyatakan aturan untuk menentukan pajang busur yaitu mengganti luas lingkaran pada aturan menentukan luas juring dengan keliling lingkaran.

Skema terkait menentukan panjang busur yang sudah dibentuk mampu dimunculkan NY pada pemecahan masalah. NY dapat menentukan panjang jari-jari menggunakan aturan tersebut. Selanjutnya NY dapat menentukan luas juring tanpa intervensi dari peneliti karena skema sudah dimiliki dan dimunculkan sendiri. Langkah selanjutnya adalah menentukan luas segitiga sama kaki AOC. Tanpa intervensi dari peneliti, NY dapat menentukan luas segitiga sama kaki karena sudah memiliki skema tersebut dan berhasil dimunculkan sendiri. Terakhir, NY dengan tepat menentukan luas tembereng.

Selesai pengerjaan NY, peneliti menanyakan apakah sudah yakin bahwa jawabannya tepat. Pertanyaan tersebut membuat NY ragu kemudian memeriksa kembali pekerjaannya sampai NY menyatakan yakin. Defragmentasi yang dilakukan membuat struktur berpikir NY sesuai dengan struktur masalah. Struktur berpikir NY dalam memecahkan masalah geometri setelah defragmentasi disajikan pada Diagram gambar 2 dengan keterangan diagram disajikan pada tabel 2.

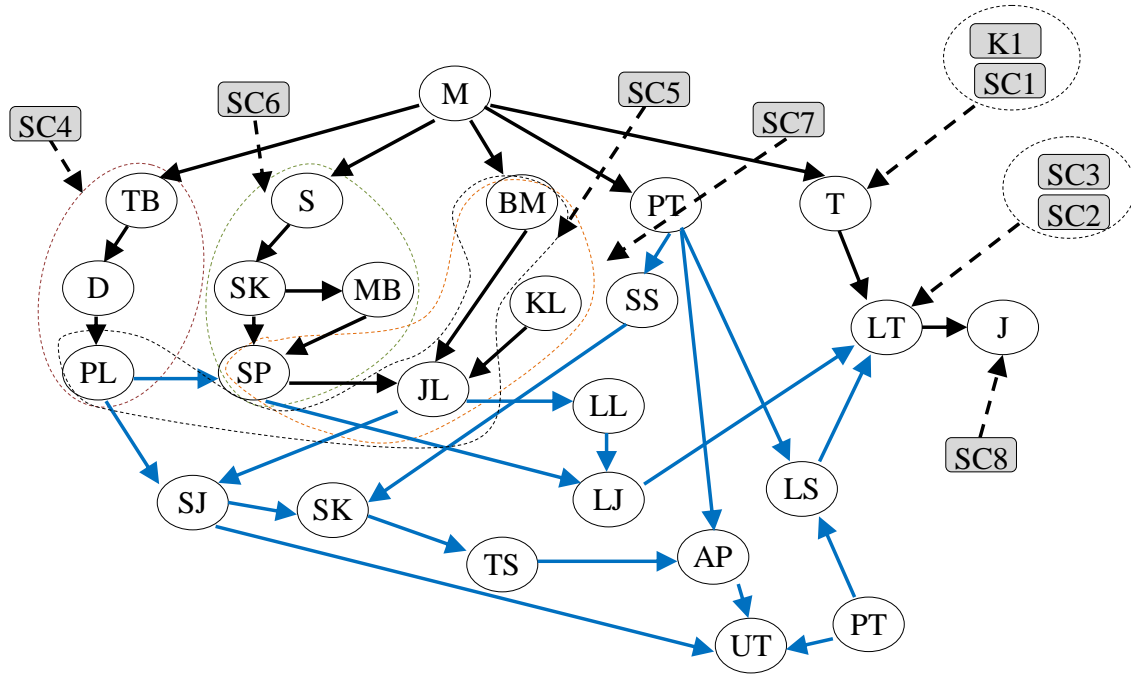

Keterangan:

Langkah Pemecahan masalah

Proses defragmentasi

Alur Pemecahan Masalah

Tanpa Intervensi

Setelah Pemunculan Skema

$\longrightarrow$ Alur Pemecahan Masalah

$\ldots$ Menunjuk Keterangan

Gambar 2. Diagram Struktur Berpikir NY dalam Memecahkan Masalah Geometri Setelah Defragmentasi 
Tabel 2. Keterangan Gambar Struktur Berpikir NY dalam Memecahkan Masalah Geometri Setelah Defragmentasi

\begin{tabular}{|c|c|}
\hline Kode & Keterangan \\
\hline M & Diberikan masalah 1 Tugas 2 \\
\hline TB & Menyebutkan $\overline{A B}$ tali busur terpanjang \\
\hline $\mathrm{S}$ & Menyebutkan ukuran $\angle C B A$ yaitu $53^{\circ}$ \\
\hline $\mathrm{BM}$ & $53 \pi$ \\
\hline $\begin{array}{c}\mathrm{PT} \\
\mathrm{T}\end{array}$ & Menyebutkan panjang busur $A C$ minor $\frac{3 \pi}{9} \mathrm{~cm}$ \\
\hline LT & Menyebutkan panjang tali busur $A C 16 \mathrm{~cm}$ \\
\hline $\mathrm{D}$ & Menjelaskan hal yang ditanyakan yaitu luas daerah yang diarsir adalah tembereng \\
\hline PL & Menjelaskan bahwa luas tembereng adalah selisih dari luas juring pmbentuk tembereng dengan segitiga pembentuk tembereng \\
\hline SK & Menjelaskan bahwa tali busur terpanjang $\overline{A B}$ adalah diameter lingkaran \\
\hline MB & Menentukan titik pusat lingkaran yaitu titik tengah diameter (titik $O$ ) \\
\hline SP & Menjelaskan bahwa $\angle C B A$ adalah sudut keliling \\
\hline KL & Menjelaskan bahwa sudut keliling $C B A$ menghadap busur $A C$ \\
\hline $\mathrm{JL}$ & Menentukan ukuran sudut pusat lingkaran menghadap busur $A C(\angle A O C)$ \\
\hline LL & Menjelaskan aturan menentukan keliling lingkaran \\
\hline LJ & Menentukan jari-jari lingkaran melalui aturan menentukan panjang busur lingkaran \\
\hline SS & Menentukan luas lingkaran \\
\hline SJ & Menentukan luas juring \\
\hline SK & Menjelaskan bahwa tali busur $A C$ adalah sisi segitiga pembentuk tembereng \\
\hline $\mathrm{TS}$ & Menjelaskan bahwa $\overline{O A}=\overline{O C}$ yang panjangnya setengah jari-jari lingkaran \\
\hline AP & Menjelaskan bahwa segitiga pembentuk tembereng $(A O C)$ segitiga sama kaki \\
\hline UT & Membuat garis tinggi segitiga sama kaki \\
\hline PT & Menjelaskan bahwa garis tinggi membagi $\overline{A C}$ menjadi dua sama panjang \\
\hline LS & Menentukan tinggi segitiga sama kaki \\
\hline $\mathrm{J}$ & Menggunakan aturan pythagoras untuk menentukan tinggi segitiga \\
\hline $\mathrm{K} 1$ & Menentukan luas segitiga sama kaki $A O C$ \\
\hline $\mathrm{SC} 1$ & Menyimpulkan jawaban hasil pemecahan masalah \\
\hline \multirow[t]{3}{*}{$\mathrm{SC} 2$} & $\begin{array}{l}\text { Pemberian konflik kognitif untuk memperbaiki gagasan NY bahwa dapat dibuat lingkaran dengan diameter tali busur } A C \text { dan busur } \\
A C\end{array}$ \\
\hline & Scaffolding pembentukan skema terkait konsep tembereng (tugas 1 nomor 3) \\
\hline & Scaffolding pembentukan skema terkait menentukan luas tembereng (tugas 1 nomor 3 ) \\
\hline SC3 & Scaffolding pemunculan skema terkait tembereng dan luasnya pada masalah 1 tugas 2 \\
\hline SC4 & Scaffolding pemunculan skema terkait diameter adalah tali busur terpanjang \\
\hline SC5 & Scaffolding pemunculan skema terkait konsep juring \\
\hline SC6 & Scaffolding pembentukan skema terkait hubungan sudut pusat dan sudut keliling (tugas 1 nomor 2 ) \\
\hline SC7 & Scaffolding pembentukan skema terkait menentukan panjang busur lingkaran (tugas 1 nomor 4 ) \\
\hline SC8 & Scaffolding untuk NY melakukan refleksi atau memeriksa kembali pengerjaannya \\
\hline
\end{tabular}

\section{Deskripsi Struktur Berpikir NS dalam Memecahkan Masalah Geometri Sebelum Defragmentasi}

Masalah geometri yang diberikan tidak dapat dipecahkan dengan baik oleh NS. Struktur berpikirnya dalam memecahkan masalah belum sesuai dengan struktur masalah. Dalam pengerjaannya, NS menentukan keliling lingkaran kemudian menentukan luas daerah yang diarsir dengan mengalikan panjang busur $A C$ dengan keliling lingkaran yang diperoleh. Jawaban NS disajikan pada gambar 2.

$$
\begin{array}{rlrl}
1.5 & =2 . \pi . r^{2} & l \text { daerahyg diarsir } & =\frac{53 \pi}{9} \times 16 \pi \\
& =2 . \pi .8 & & =\frac{840 \pi^{2}}{9} \\
& =16 \pi & & 94.2 \pi^{2}
\end{array}
$$

\section{Gambar 2. Jawaban NS dari Masalah Geometri}

Ketika diminta untuk menjelaskan pekerjaannya, NS menyebutkan semua informasi pada masalah, namun tidak menjelaskan maksud dari tali busur terpanjang. Ternyata, skema tersebut belum dimiliki oleh NS. Pada soal pelacak yang diberikan, NS setuju bahwa tali busur suatu lingkaran merupakan diameter karena tali busur lingkaran melewati titik pusat 
lingkaran. Hal ini berarti NS tidak memahami bahwa tidak semua tali busur melewati titik pusat lingkaran. Hal ini menyebabkan NS tidak memahami bahwa tali busur terpanjang dari suatu lingkaran merupakan diameter. Selain skema terkait diameter dan tali busur, beberapa skema terkait lingkaran juga belum dimiliki NS di antaranya skema terkait menentukan luas tembereng, skema terkait menentukan hubungan ukuran sudut pusat dan sudut keliling, serta skema terkait menentukan panjang busur lingkaran. NS tidak menjelaskan secara rinci konsep tembereng dan luasnya. NS juga salah dalam menentukan panjang busur karena menggunakan sudut keliling bukan sudut pusat. Skema yang belum terbentuk akan dilakukan defragmentasi sehingga dapat dimunculkan dalam pemecahan masalah.

Dalam penjelasan yang diberikan NS untuk jawaban yang ditulisnya, NS menambahkan bahwa sebenarnya NS mengetahui daerah yang diarsir adalah tembereng. Namun, NS tidak mengetahui cara menentukannya. NS menganggap daerah yang diarsir dapat ditentukan dengan mengurangkan luas segitiga $A B C$ dari luas setengah lingkaran. Jawaban NS menunjukkan hanya skema terkait menentukan keliling lingkaran yang muncul.

Melalui soal pelacak yang diberikan dapat diketahui ternyata NS juga telah memiliki skema terkait menentukan luas juring dan segitiga sama kaki. NS mampu menentukan luas juring dengan diketahui sudut pusat dan diameter dengan tepat. NS juga mampu menentukan luas segitiga sama kaki yang diketahui ketiga sisinya melalui menentukan tinggi segitiga dengan pythagoras terlebih dahulu. Deskripsi struktur berpikir NS sebelum defragmentasi disajikan pada Diagram 3 dengan keterangan diagram disajikan pada tabel 3.



Gambar 3. Diagram Struktur Berpikir NS Memecahkan Masalah Geometri Sebelum Defragmentasi

Tabel 3. Keterangan Gambar Struktur Berpikir NS Memecahkan Masalah Geometri Sebelum Defragmentasi

\begin{tabular}{cl}
\hline Kode & \multicolumn{1}{c}{ Keterangan } \\
\hline $\mathrm{M}$ & Diberikan masalah 1 Tugas 2 \\
$\mathrm{~TB}$ & Menyebutkan $\overline{A B}$ tali busur terpanjang \\
$\mathrm{S}$ & Menyebutkan ukuran $\angle C B A 53^{\circ}$ \\
$\mathrm{PB}$ & \\
& Menyebutkan panjang busur $A C$ minor $\frac{53 \pi}{9} \mathrm{~cm}$ \\
$\mathrm{PT}$ & Menyebutkan panjang tali busur $A C 16 \mathrm{~cm}$ \\
$\mathrm{~T}$ & Menyebutkan hal yang ditanyakan yaitu daerah yang diarsir (tidak ada penjelasan bahwa daerah yang diarsir adalah luas tembereng) \\
$\mathrm{D}$ & Menyebutkan bahwa tali busur AC yang panjangnya $16 \mathrm{~cm}$ adalah diameter lingkaran \\
$\mathrm{KL}$ & Menentukan keliling lingkaran \\
$\mathrm{LT}$ & Menentukan luas tembereng dengan mengalikan panjang busur $A C$ dengan keliling lingkaran
\end{tabular}

\section{Deskripsi Struktur Berpikir NS dalam Memecahkan Masalah Geometri Saat Defragmentasi}

Defragmentasi pertama pada NS untuk memperbaiki gagasan awal yang menyatakan bahwa luas daerah yang diarsir (tembereng) dapat ditentukan melalui selisih luas setengah lingkaran dengan segitiga $A B C$. Intervensi yang diberikan berupa scaffolding. Dalam wawancara, NS yakin bahwa daerah yang diarsir adalah tembereng. Namun, NS ragu ketika ditanya apakah yakin bahwa luasnya adalah selisih luas lingkaran dengan segitiga $A B C$. Kemudian, NS mencermati kembali gambar pada masalah dan menyadari bahwa ada daerah yang ikut dicari luasnya padahal tidak perlu yaitu luas tembereng dengan busur $B C$. Dengan demikian, NS mengetahui bahwa daerah yang diarsir adalah tembereng dan untuk menentukan luasnya menggunakan aturan menentukan luas tembereng yang NS tidak mengetahuinya.

Langkah selanjutnya, bagi peneliti adalah memberikan intervensi untuk membentuk skema terkait menentukan luas tembereng. Melalui intervensi yang diberikan melalui scaffolding, diketahui bahwa sebenarnya NS memahami aturan menentukan tembereng yaitu selisih antara luas juring dengan segitiga pembentuk tembereng. Skema yang sudah dimiliki ini selanjutnya mampu dimunculkan oleh NS pada pemecahan masalah yang diberikan. Namun, NY mengalami kesalahan dalam menentukan juring pembentuk tembereng. Sebelumnya telah diketahui bahwa NS telah memiliki skema terkait juring dan menentukan luasnya. Namun, skema tersebut tidak berhasil dimunculkan pada pemecahan masalah. Dengan demikian, 
diberikan intervensi melalui scaffolding dan disekuilibrasi. Melalui pertanyaan yang diberikan, yaitu "juringnya yang mana?", “juring itu dibatasi apa?", "manakah busur dan jari-jarinya?", mampu mengarahkan NS pada juring yang dimaksud. NS menyebutkan bahwa titik pusat lingkaran adalah titik tengah ruas garis $A B$. Ketika ditanya apakah yakin bahwa titik pusatnya ditengah ruas garis $A B$, NS terdiam dan menjadi tidak yakin (terjadi disekuilibrasi). Akibat disekuilibrasi, NS tidak yakin dengan titik pusat lingkaran yang dibuatnya. Oleh karena itu, diberikan intervensi melalui scaffolding seperti dialog berikut.

$\begin{array}{lll}P & : & \text { Titik pusat itu harus apa? } \\ N S & : & \text { Berada di tengah lingkaran } \\ P & : & \text { Apanya diameter? } \\ N S & : & \text { Pembelahnya } \\ P & : & \text { Berarti ada di diameter gak? } \\ N S & : & \text { Iya, titik tengahnya diameter } \\ P & : & \text { Oke, kalo AB ini diameter bukan? }\end{array}$

Melalui pertanyaan yang diberikan dapat diketahui bahwa NS memahami konsep titik pusat maupun diameter. Namun, ketika ditanya apakah ruas garis $A B$ adalah diameter, NS menjadi ragu. NS menyebutkan bahwa $A B$ adalah ruas garis terpanjang seperti yang diketahui pada masalah. selanjutnya peneliti memberikan intervensi menggunakan pernyataan "tali busur suatu lingkaran merupakan diameter". NS menjelaskan bahwa tali busur lingkaran melewati titik pusat lingkaran sehingga disebut diameter. Ketika ditanya apakah semua tali busur melewati titik pusat, NS dengan yakin menjawab tidak. Selanjutnya peneliti memberikan pertanyaan "apakah diameter lingkaran merupakan tali busur?" dan NS menjawab iya. Dari dua pertanyaan yang diberikan NS menyimpulkan bahwa tidak semua tali busur lingkaran adalah diameter. NS menegaskan bahwa tali busur dapat menjadi diameter ketika tali busur tersebut yang terpanjang. Dengan demikian, NS yakin bahwa ruas garis $A B$ adalah diameter dan titik pusat lingkaran berada di tengah ruas garis tersebut.

Setelah diberikan intervensi seperti di atas, NS mampu menentukan juring pembentuk lingkaran dengan tepat. Namun NS mengalami kendala dalam menentukan luas juring karena panjang jari-jari belum diketahui dan NS tidak mengetahui cara menentukannya. Oleh karena itu, diberikan defragmentasi untuk membentuk skema terkait menentukan panjang busur lingkaran yang belum dimiliki. Defragmentasi dilakukan melalui scaffolding seperti dialog berikut.

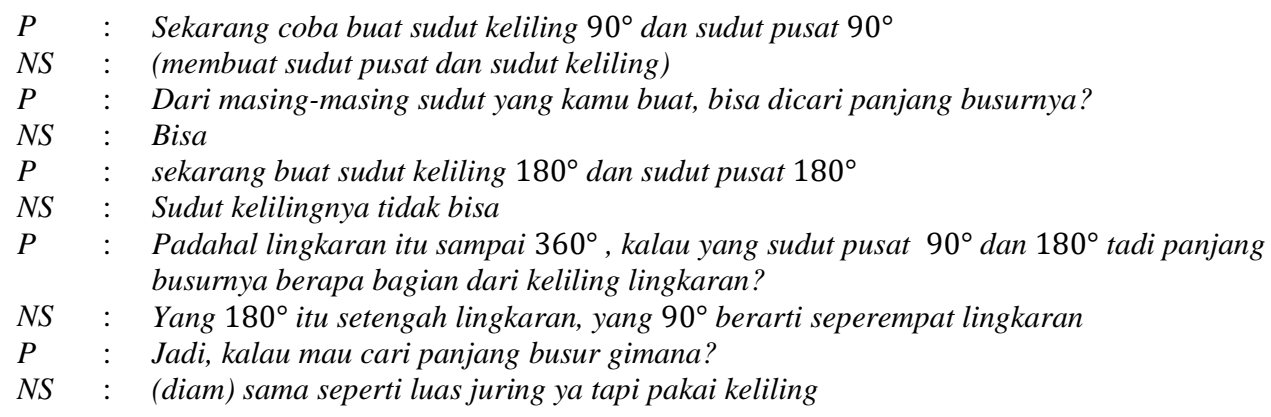

Dalam wawancara, NS menyadari bahwa untuk menentukan panjang busur lingkaran menggunakan sudut pusat. Aturan yang dipakai untuk menentukan panjang busur lingkaran seperti aturan untuk menentukan luas juring hanya saja menggunakan keliling lingkaran bukan luas lingkaran. Selanjutnya, NS mampu memunculkan skema terkait menentukan panjang busur untuk menentukan panjang jari-jarinya dengan tepat.

Dalam menentukan luas juring, NS mengalami kendala dalam menentukan ukuran sudut pusat juring. Sebelum diberikan intervensi, NS memahami sudut keliling sebagai penjumlahan dua sudut. Ketika diketahui sudut $A O C$ dan $B O C$ masing-masing adalah sudut pusat, NS menentukan ukuran sudut keliling dengan menjumlahkan ukuran kedua sudut pusat menjadi sudut $A C B$ yang tidak tepat. Oleh karena itu, peneiti memberikan intervensi terlebih dahulu terkait konsep penjumlahan sudut melalui scaffolding. Peneliti memberikan pertanyaan "ingat lagi penjumlahan sudut, kalau sudut $A O C$ ditambah sudut $B O C$, jadinya sudut $A C B$ atau $A O C$ ?". Terkait pertanyaan tersebut, NS terdiam dan akhirnya menyatakan bahwa NS lupa tentang penjumlahan sudut. Scaffolding selanjutnya disajikan pada dialog berikut.




Pada wawancara tersebut, NS menyadari kesalahannya dalam menjumlahkan sudut. Begitupula hubungan ukuran sudut pusat dan sudut keliling yang berhasil diingat oleh NS beserta syarat yang harus dipenuhi supaya aturan tersebut dapat dipakai, yaitu kedua sudut menghadap busur yang sama. Setelah pemberian intervensi, NS mampu menentukan ukuran sudut pusat pada juring dengan tepat. Selanjutnya, NS mampu menentukan luas juring dengan tepat tanpa intervensi dari peneliti yang mana skema terkait luas juring sudah dimiliki oleh NS.

Langkah selanjutnya dalam menentukan luas tembereng adalah menentukan luas segitiga sama kaki pembentuk tembereng. Namun, NS tidak menyadari bahwa segitiga pembentuk tembereng adalah segitiga sama kaki. Oleh karena itu, diberikan scaffolding dengan memberikan pertanyaan untuk mencermati kembali apakah ada kaitan antara sisi segitiga segitiga dengan unsur lingkaran. Akibat intervensi NS dapat menentukan luas segitiga sama kaki dengan baik seperti skema yang sudah dimilikinya.

Di akhir pengerjaan, peneliti menanyakan kepada NS apakah pekerjaannya sudah tepat. NS mejawab "yakin" namun dengan keraguan kemudian memeriksa kembali pekerjaannya sampai NS yakin bahwa jawabannya sudah tepat. Defragmentasi yang dilakukan telah membuat struktur berpikir NS dalam memecahkan masalah gometri sesuai dengan struktur masalah. Struktur berpikir NS dalam memecahkan masalah geometri setelah defragmentasi disajikan pada Diagram gambar 4 dengan keterangan diagram disajikan pada tabel 4.

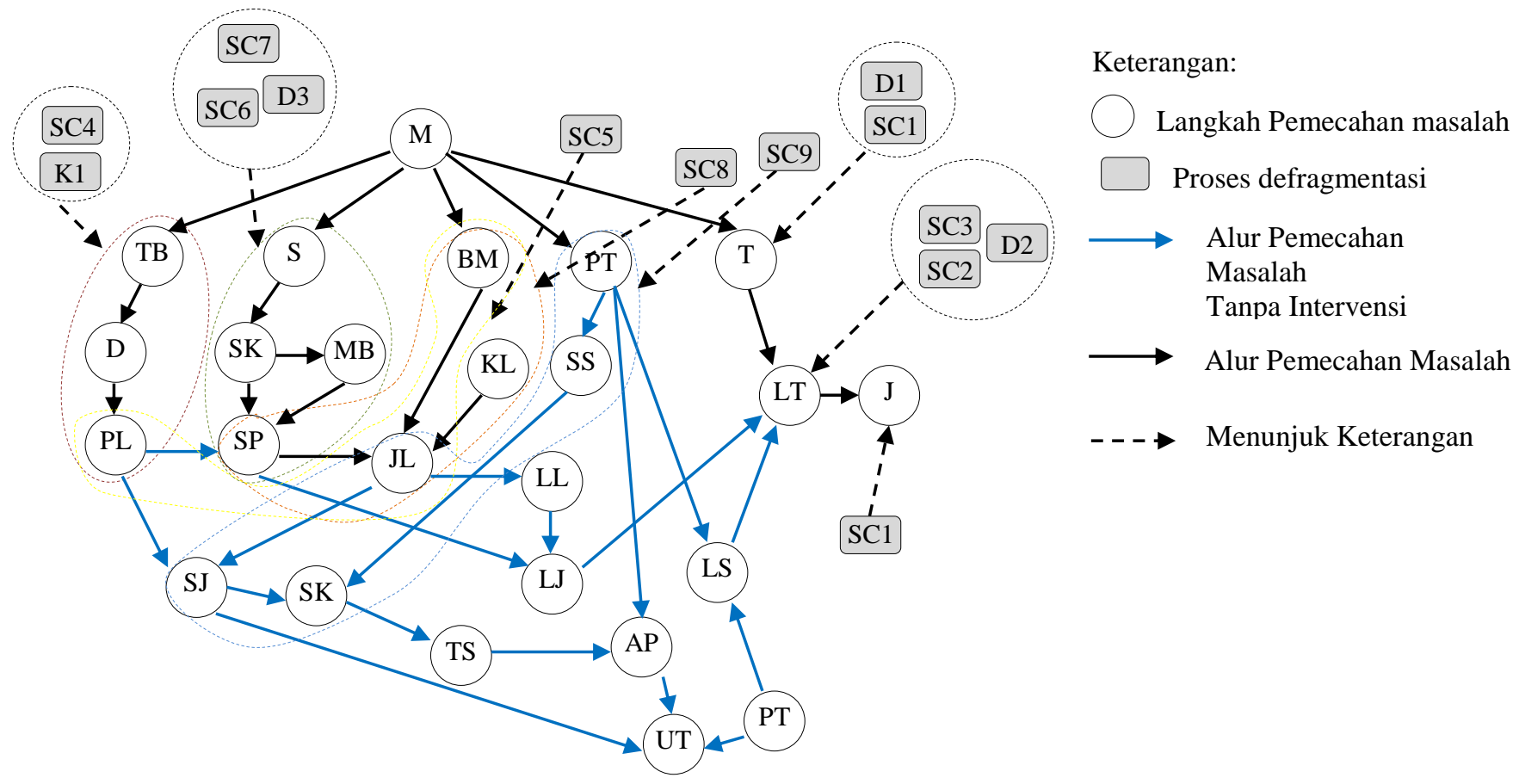

Gambar 4. Diagram Struktur Berpikir NS dalam Memecahkan Masalah Geometri Setelah Defragmentasi 
Tabel 4. Keterangan Gambar Struktur Berpikir NS dalam Memecahkan Masalah Geometri Setelah Defragmentasi

\begin{tabular}{|c|c|}
\hline Kode & Keterangan \\
\hline M & Diberikan masalah 1 Tugas 2 \\
\hline TB & Menyebutkan $\overline{A B}$ tali busur terpanjang \\
\hline $\mathrm{S}$ & Menyebutkan ukuran $\angle C B A$ yaitu $53^{\circ}$ \\
\hline $\mathrm{BM}$ & 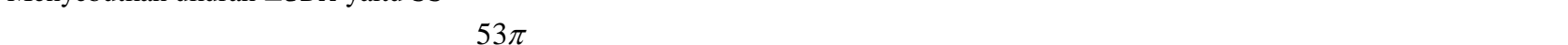 \\
\hline & Menyebutkan panjang busur $A C$ minor $\frac{5 \pi}{9} \mathrm{~cm}$ \\
\hline PT & Menyebutkan panjang tali busur $A C 16 \mathrm{~cm}$ \\
\hline $\mathrm{T}$ & Menjelaskan hal yang ditanyakan yaitu luas daerah yang diarsir adalah tembereng \\
\hline LT & Menjelaskan bahwa luas tembereng adalah selisih dari luas juring pmbentuk tembereng dengan segitiga pembentuk tembereng \\
\hline $\mathrm{D}$ & Menjelaskan bahwa tali busur terpanjang $\overline{A B}$ adalah diameter lingkaran \\
\hline PL & Menentukan titik pusat lingkaran yaitu titik tengah diameter (titik $O$ ) \\
\hline SK & Menjelaskan bahwa $\angle C B A$ adalah sudut keliling \\
\hline MB & Menjelaskan bahwa sudut keliling $C B A$ menghadap busur $A C$ \\
\hline SP & Menentukan ukuran sudut pusat lingkaran menghadap busur $A C(\angle A O C)$ \\
\hline KL & Menjelaskan aturan menentukan keliling lingkaran \\
\hline $\mathrm{JL}$ & Menentukan jari-jari lingkaran melalui aturan menentukan panjang busur lingkaran \\
\hline LL & Menentukan luas lingkaran \\
\hline LJ & Menentukan luas juring \\
\hline SS & Menjelaskan bahwa tali busur $A C$ adalah sisi segitiga pembentuk tembereng \\
\hline SJ & Menjelaskan bahwa $\overline{O A}=\overline{O C}$ yang panjangnya setengah jari-jari lingkaran \\
\hline SK & Menjelaskan bahwa segitiga pembentuk tembereng $(A O C)$ segitiga sama kaki \\
\hline TS & Membuat garis tinggi segitiga sama kaki \\
\hline AP & Menjelaskan bahwa garis tinggi membagi $\overline{A C}$ menjadi dua sama panjang \\
\hline UT & Menentukan tinggi segitiga sama kaki \\
\hline PT & Menggunakan aturan pythagoras untuk menentukan tinggi segitiga \\
\hline LS & Menentukan luas segitiga sama kaki $A O C$ \\
\hline $\mathrm{J}$ & Menyimpulkan jawaban hasil pemecahan masalah \\
\hline D1 & $\begin{array}{l}\text { Disekuilibrasi untuk perbaikan gagasan NS tentang luas daerah yang diarsir adalah selisih luas setengah lingkaran dengan diameter } \\
A B \text { dengan segitiga } A B C\end{array}$ \\
\hline $\mathrm{SC} 1$ & $\begin{array}{l}\text { Scaffolding untuk perbaikan gagasan NS tentang luas daerah yang diarsir adalah selisih luas setengah lingkaran dengan diameter } A B \\
\text { dengan segitiga } A B C\end{array}$ \\
\hline $\mathrm{SC} 2$ & Scaffolding pembentukan skema terkait menentukan luas tembereng (tugas 1 nomor 3 ) \\
\hline SC3 & Scaffolding pemunculan skema terkait menentukan luas tembereng pada masalah 1 tugas 2 \\
\hline D2 & Disekuilibrasi pemunculan skema terkait menentukan luas tembereng pada masalah 1 tugas 2 \\
\hline K1 & Pemberian konflik kognitif untuk pembentukan skema terkait diameter adalah tali busur terpanjang \\
\hline SC4 & Scaffolding pembentukan skema terkait diameter adalah tali busur terpanjang \\
\hline SC5 & Scaffolding pemunculan skema terkait konsep juring pada pemecahan masalah 1 tugas 2 \\
\hline SC6 & Scaffolding skema terkait penjumlahan sudut \\
\hline SC7 & Scaffolding pembentukan skema terkait hubungan sudut pusat dan sudut keliling (tugas 1 nomor 2) \\
\hline D3 & Disekuilibrasi pembentukan skema terkait hubungan sudut pusat dan sudut keliling (tugas 1 nomor 2) \\
\hline $\mathrm{SC} 8$ & Scaffolding pembentukan skema terkait menentukan panjang busur lingkaran (tugas 1 nomor 4 ) \\
\hline SC9 & Scaffolding pemunculan skema terkait segitiga sama kaki \\
\hline $\mathrm{SC} 10$ & Scaffolding untuk NS melakukan refleksi atau memeriksa kembali pengerjaannya \\
\hline
\end{tabular}

\section{PEMBAHASAN}

Dalam memecahkan masalah geometri, siswa impulsif mengalami kesalahan dalam menentukan gagasan awal pemecahan masalah. NY menganggap daerah yang diarsir (tembereng) merupakan setengah lingkaran dengan diameter $A C$. Untuk memperbaiki gagasan ini diberikan konflik kognitif melalui pemberian bangun lingkaran sesungguhnya untuk dibandingkan dengan lingkaran yang dibuat NY sehingga konsep lingkaran dapat dipahami dengan baik. Subanji (2016) menegaskan bahwa konflik kognitif efektif untuk memperbaiki kesalahan siswa, sedangkan NS mengalami kesalahan dengan menganggap luas daerah yang diarsir atau tembereng dapat ditentukan melalui selisih luas setengah lingkaran dengan luas segitiga $A B C$ yang menyisakan luas tembereng lainnya. Untuk memperbaikinya diberikan disekuilibrasi melalui pertanyaan "kalau caramu itu, lha ini gimana, yakin?" dilanjutkan dengan scaffolding berupa pertanyaan dorongan maupun untuk memberikan penjelasan dan justifikasi. Menurut Anghileri(2006) scaffolding tersebut berada pada level 2 yaitu reviewing.

Skema terkait konsep tembereng belum dimiliki NY yang mengakibatkan masalah tidak dapat dipahami dengan baik. Untuk membentuk skema tersebut dilakukan scaffolding dengan meminta NY untuk menggambarkan atau memvisualisaikan ide atau gagasan yang dimiliki. Scaffolding ini juga merupakan level 2 yaitu reviewing (Anghileri, 2006). Lanjutan dari konsep 
tembereng yaitu aturan untuk menentukan luas tembereng juga belum dimiliki bahkan bagi kedua siswa. Dengan demikian, diberikan scaffolding berupa pertanyaan dorongan maupun untuk meminta penjelasan dan justifikasi. Scaffolding tersebut merupakan reviewing pada level 2 (Anghileri, 2006). Setelah proses pembentukan skema selesai, kedua siswa tidak mampu memunculkannya pada pemecahan masalah sehingga juga diberikan scaffolding berupa reviewing yaitu memberikan pertanyaan dorongan.

Pada saat pemberian scaffolding untuk pemunculan skema, terjadi kesalahan pada NS dalam menentukan titik pusat lingkaran. Oleh karena itu, diberikan disekuilibrasi untuk membuat siswa ragu seperti "yakin, disitu?" serta scaffolding. Scaffolding ini dilakukan juga untuk membentuk skema terkait tali busur merupakan diameter sehingga siswa menyadari bahwa tali busur terpanjang merupakan diameter. Pada NS diberikan scaffolding level 2 yaitu reviewing dan restructuring(Anghileri, 2006) berupa pertanyaan dorongan dan pertanyaan untuk membuat penekanan pada siswa diakhir dialog. Berkaitan dengan skema ini, dilakukan pula defragmentasi pada NY untuk memunculkan skema untuk menyadarkan bahwa tali busur terpanjang adalah diameter melalui scaffolding level 2 yaitu explaining, reviewing, dan restructuring berupa perintah untuk mencermati kembali informasi yang ada, pertanyaan dorongan dan pertanyaan untuk membuat penekanan pada siswa di akhir dialog.

Siswa impulsif mengalami kesalahan dalam menentukan juring pada masalah padahal skema yang terkait sudah dimilikinya. Pada NY diberikan disekuilibrasi berupa pertanyaan sehingga siswa ragu dengan juring salah yang dibuatnya dan scaffolding level 2 yaitu explaining dan reviewing (Anghileri, 2006) berupa perintah untuk mencermati kembali masalah dan pertanyaaan dorongan. Sedangkan pada NS diberikan scaffolding level 2 yaitu reviewing(Anghileri, 2006) berupa pertanyaan untuk meminta siswa memberikan alasan dari gagasan yang dibuatnya.

Selanjutnya dalam menentukan luas juring kedua subjek mengalami kesulitan. Hal ini terjadi karena skema terkait hubungan sudut pusat dan sudut keliling belum dimiliki. Oleh karena itu diberikan scaffolding level 2 yaitu reviewing(Anghileri, 2006) pada NS berupa pertanyaan arahan maupun pertanyaan untuk meminta penjelasan. Pada NY diberikan scaffolding level 2 yaitu reviewing dan restructuring(Anghileri, 2006) berupa pertanyaan dorongan pertanyaan untuk membuat penekanan pada siswa. Ketika proses defragmentasi, muncul skema lain yang tidak diduga yaitu terkait penjumlahan sudut. Skema yang dimiliki NS belum tepat sehingga dilakukan scaffolding level 2 yaitu reviewing(Anghileri, 2006) berupa pemberian pengertian penjumlahan sudut secara umum. Hal ini dilakukan karena NS tidak mengingatnya dengan baik. Scaffolding dilanjutkan dengan pemberian pertanyaan dorongan. Skema-skema yang sudah dibentuk dapat dimuculkan sendiri oleh siswa dalam memecahan masalah.

Kesulitan lain dalam menentukan luas juring dikarenakan skema terkait menentukan panjang busur belum dimiliki siswa. Pada kedua siswa diberikan scaffolding level 2 yaitu explaining dan reviewing(Anghileri, 2006) berupa perintah untuk mencermati kembali masalah sehingga menemukan informasi yang dibutuhkan dan pemberan pertanyaan arahan serta model paralel untuk memberikan pemahaman kepada siswa. Model berupa gambar dibuat oleh siswa untuk diambil kesimpulannya. Skema yang sudah terbentuk ini selanjutnya dapat dimunculkan sendiri oleh siswa dalam memecahkan masalah.

Dalam memecahkan masalah, kesulitan terkait segitiga sama kaki dialami oleh NS. Siswa tidak menyadari bahwa segitiga pembentuk tembereng adalah sama kaki sehingga diberikan scaffolding level 2 yaitu explaining dan reviewing (Anghileri, 2006). Scaffolding yang diberikan berupa perintah untuk mencermati kembali gambar pada proses pemecahan masalah yang dibuatnya. Selain itu diberikan juga pertanyaan arahan sehingga siswa mengatahui bahwa dua sisi segitiga adalah jari-jari lingkaran sehingga segitiga tersebut adalah segitiga sama kaki.

Defragmentasi dilakukan untuk membantu siswa supaya melakukan refleksi. Ketika siswa ditanya apakah pekerjaan dan jawabannya sudah benar, siswa mengalami keraguan sehingga membuatnya memeriksa kembali pekerjaannya. Scaffolding yang diberikan masuk pada level 1 yaitu environmental provisions (Anghileri, 2006). Hal ini perlu dilakukan untuk membiasakan siswa mencermati kembali pekerjaannya supaya apa yang ditulis siswa dapat dipertanggungjawabkan.

\section{SIMPULAN}

Berdasarkan hasil penelitian serta pembahasan yang telah diuraikan dapat disimpulkan bahwa pada siswa impulsif banyak skema yang belum muncul pada pemecahan masalah meskipun beberapa skema sebenarnya sudah dimiliki. Defragmentasi dilakukan untuk memunculkan skema tersebut maupun untuk membentuk skema yang dibutuhkan dalam pemecahan masalah. Skema-skema yang berhasil dibentuk tidak semua dapat dimunculkan sendiri oleh siswa. Peneliti masih perlu memberikan intervensi supaya skema tersebut muncul untuk memecahkan masalah.

Defragmentasi pada siswa impulsif diberikan dalam bentuk konflik kognitif, disekuilibrasi, dan scaffolding. Konflik kognitif yang diberikan berkaitan dengan memperbaiki suatu konsep. Disekuilibrasi dilakukan untuk membuat siswa ragu dengan jawaban yang disampaikan sehingga menyadari kesalahannya. Disekuilibrasi diberikan bersamaan dengan proses scaffolding. Scaffolding yang diberikan berada pada level 1 dan 2 . Pada level 1 (environmental provisions) diberikan berupa pertanyaan yang membantu siswa melakukan refleksi atau memeriksa kembali pekerjaannya sehingga jawaban yang diperoleh sudah tepat. Pada level 2 scaffolding diberikan berupa explaining, reviewing, dan restructuring. Pada explaining siswa diberikan perintah untuk mencermati kembali masalah sehingga menemukan informasi yang dibutuhkan untuk memecahkan masalah. Pada reviewing siswa diberikan pertanyaan dorongan, pertanyaan untuk meminta penjelasan, informasi terkait suatu konsep secara umum, serta pemberian model paralel untuk memberikan pemahaman kepada siswa. Pada resctructuring diberikan pertanyaan untuk membuat penegasan atau penekanan yang dilakukan di akhir dialog scaffolding. 
Defragmentasi yang dilakukan pada siswa impulsif menunjukkan bahwa pemahaman awal terkait suatu konsep matematika harus ditanamkan dengan baik. Selain itu, kebiasaan memberikan masalah dapat membuat siswa terlatih untuk dapat memecahkan masalah yang lebih kompleks. Untuk pembelajaran di kelas ketika siswa mengalami kesulitan sebaiknya dibantu melalui scaffolding atau disekuilibrasi dan membiarkan siswa berpikir supaya kemampuannya dapat berkembang. Penelitian yang telah dilakukan ini dapat dikembangkan untuk materi selain geometri atau untuk subjek dengan tingkat pendidikan yang lebih rendah maupun lebih tinggi.

\section{DAFTAR RUJUKAN}

Anghileri, J. (2006). Scaffolding Practices That Enhance Mathematics Learning. Journal of Mathematics Teacher Education, 9(1), 33-52. https://doi.org/10.1007/s10857-006-9005-9

Aydogdu, M., \& Kesan, C. (2014). Research on Geometry Problem Solving Strategies Used by Elementary Mathematics Teacher Candidates. Journal of Educational and Instructionl Studies in the World, 4(1), 43-52

Barnard, T., \& Tall, D. (1997). Cognitive Units, Connections, and Mathematical Proof. Paper Publishing in Proceedings of PME 21, 2, 41-48

Biber, C., Tuna, A., \& Korkmaz, S. (2013). The Mistakes and the Misconceptions of the Eighth Grade Students on the Subject of Angles. European Journal of Science and Mathematics Education, 1(2), 50-59

Gal, H., \& Linchevcki. (2010). To See or not to See Analyzing Difficulties in Geometry from Perspective of Visual Perception. Educational Studies in Mathematics, 74, 163-183

Hassanabad, S. M., Shahvarani, A., \& Behzadi, M. H. (2012). The Role of Problem Solving Method on the Improvement of Mathematical Learning. Mathematics Education Trends and Research, 1-9

Kaur, B., \& Toh, P. C. (2016). $21^{\text {st }}$ Century Competencies in Mathematics Classroom. Singapore: World Scientific

Kultuca, T. (2013). The Effect of Geometry Instruction with Dynamic Geometry Software. Global Science Research Journals, l(1), 1509-1518

Liu, Y., \& Ginther, D. (1999). Cognitive Styles and Distance Education. Journal of Distance Learning Administration State University of Georgia, 2(3)

Madden, S. (2017). Polygons, Pillars and Pavilions: Discovering Connections between Geometry and Architecture. Journal of Catholic Education, 20(2), 215-227. https://doi.org/10.15365/joce.2002112017

McKay, M., \& Fanning, P. (2000). Self Esteem Third Edition. United Stated of America: New Harbinger Publications, Inc

NCTM. (2000). Principles and Standards for School Mathematics. NCTM: Reston

Novotná, J. (2014). Problem Solving in School Mathematics Based on Heuristic Strategies. Journal on Efficiency and Responsibility in Education and Science, 7(1), 1-6. https://doi.org/10.7160/eriesj.2014.070101

Permendikbud Nomor 24 Tahun 2016 Tentang Kompetensi Inti dan Kompetensi Dasar Kurikulum 2013 pada Pendidikan Dasar dan Menengah. (2016).

Pimta, S., Tayruakham, S., \& Nuangchale, P. (2009). Factors Influencing Mathematic Problem-Solving Ability of Sixth Grade Students. Journal of Social Sciences, 5(4), 381-385. https://doi.org/10.3844/jssp.2009.381.385

Santrock. (2011). Educationl Psychology. New york: McGraw-Hills

Seifi, M., Haghverdi, M., \& Azizmohamadi, F. (2012). Recognition of Students' Difficulties in Solving Mathematical Word Problems from the Viewpoint of Teachers. Journal of Basic and Applied Scientific Research,2(3), 2923-2928.

Selvera, N. R. (2013). Teknik Restrukturisasi Kognitif untuk Menurunkan Keyakinan Irasional pada Remaja dengan Gangguan Somatisasi. Jurnal Sains dan Praktik Psikologi, 1(1), 63-67.

Shaban, S., Ramazani, M., \& Alipoor, I. (2017). The Effect of Impulsivity vs. Reflectivity on Reading Comprehension of Iranian EFL Learners. International Journal of Education and Literacy Studies, 5(3), 52. https://doi.org/10.7575/aiac.ijels.v.5n.3p.52

Slavin, R. E. (2008). Cooperative Learning Teori, Riset dan Praktik. Bandung: Nusa Media.

Subanji. (2016). Teori Defragmentasi Struktur Berpikir dalam Mengonstruksi Konsep dan Pemecahan Masalah Matematika. UM Press.

Yilmaz, G. K., \& Koparan, T. (2015). The Effect of Designed Geometry Teaching Lesson to the Candidate Teachers' Van Hiele Geometric Thinking Level. Journal of Education and Training Studies, 4(1), 129-141. https://doi.org/10.11114/jets.v4i1.1067 